A N N A LES

UNIVERSITATIS MARIAE CURIE-SKŁODOWSKA

LUBLIN - POLONIA

VOL. LXVII, 1

SECTIO G

2020

Uniwersytet Jana Kochanowskiego w Kielcach

AGNIESZKA ŻYWICKA

agnieszka.zywicka@onet.eu

ORCID: 0000-0002-5789-8355

\title{
O współzależnościach prawa publicznego i prywatnego w regulacjach gospodarczych na przykładzie systemu oceny zgodności wyrobów - kilka refleksji
}

\begin{abstract}
A Few Reflections Concerning the Interdependence of Public and Private Law in Economic Regulations Based on the Example of the Product Conformity Assessment System
\end{abstract}

\section{WPROWADZENIE}

Dychotomiczny podział prawa na prawo publiczne i prywatne, sformułowany jeszcze w czasach starożytnych, jest zakorzeniony w tradycji kontynentalnej. Owo rozgraniczenie wywołuje jednak pewne kontrowersje w doktrynie ${ }^{1}$. Zdaniem J. Helios podział na prawo publiczne i prywatne współcześnie nadal ma istotne znaczenie, gdyż oddaje zasadnicze zróżnicowanie porządku prawnego i umożliwia teoretyczne wyodrębnienie gałęzi prawa w ramach systemu prawa ${ }^{2}$. $\mathrm{Na}$ gruncie prawa merytorycznego poza walorem teoretycznym cechuje go również wysoce istotne znaczenie praktyczne, sprowadzające się do odpowiedzi na pytanie dotyczące zakresu zastosowania poszczególnych grup przepisów³ ${ }^{3}$ Nato-

1 Odmienne stanowisko prezentuje B. Liżewski (Prawo publiczne a prawo prywatne wybrane uwagi teoretyczne na temat hybrydyzacji instytucji prawnych, „Zeszyty Naukowe KUL” 2018, nr 4, s. 47).

2 Por. J. Helios, Publicyzacja prawa prywatnego - prywatyzacja prawa publicznego w kontekście rozważań nad prawem europejskim, „Przegląd Prawa i Administracji” 2013, nr 92, s. 11.

3 Por. P. Rodziewicz, Prawo prywatne oraz prawo publiczne z perspektywy prawa międzynarodowego, „Studia Prawa Prywatnego”2017, nr 3-4. 
miast M. Zdyb twierdzi, że podziały prawa są jednak niedoskonałe, gdyż prawo jest materią złożoną ${ }^{4}$, zatem dokonywanie takiego rozgraniczenia może być problematyczne ${ }^{5}$.

W praktyce w konkretnych aktach normatywnych, zwłaszcza regulujących stosunki gospodarcze, często można napotkać trudności z definitywnym zaliczeniem konkretnego aktu normatywnego do jednej z tych klasycznych gałęzi systemu prawa. Dostosowywanie instytucji prawnych i mechanizmów prawnych do dynamiki rozwoju procesów gospodarczych powoduje bowiem pewne zatarcie tego tradycyjnego podziału systemu prawa. Dokonanie ścisłego rozgraniczenia na instytucje prawa publicznego i prawa prywatnego oraz ich zakwalifikowanie do określonego typu kategorii prawnych jest aktualnie coraz trudniejsze ${ }^{6}$. Bardzo często mamy do czynienia z aktami o złożonej naturze prawnej, zawierającymi zarówno regulacje publicznoprawne, jak i prywatnoprawne.

Powyższa koncepcja stanowi punkt odniesienia do identyfikacji w doktrynie prawa zjawiska publicyzacji prawa prywatnego i prywatyzacji prawa publicznego, ich wpływu na prawne formy działania administracji publicznej oraz hybrydyzacji instytucji prawnych, następujących szczególnie w prawie gospodarczym ${ }^{7}$. Mimo że owe zjawiska są od dawna obiektem szerokiego zainteresowania przedstawicieli nauki prawa publicznego i prywatnego, to z uwagi na ich dynamiczny charakter wymagają dalszych badań. W doktrynie stale toczą się dyskusje na temat wpływu prawa publicznego na prawo prywatne i na odwrót. Nie ma jednolitych stanowisk, które tendencje przeważają $\mathrm{w}$ aktualnych regulacjach prawnych. Aktualność tematu implikują ponadto zachodzące procesy gospodarcze i zmiany prawa, co wpływa na sposób funkcjonowania państwa i jego aparatu administracyjnego. Ta dynamika zmian w gospodarce jest wywołana rozrostem stosunków gospodarczych, ich coraz bardziej złożonym charakterem oraz podążającym za tymi procesami ustawodawcą, który stara się uchwycić regulacją publicznoprawną coraz to nowe zjawiska gospodarcze.

$\mathrm{Z}$ uwagi na rozległość stosunków gospodarczych, będących przedmiotem zainteresowania prawa publicznego gospodarczego, nie sposób w tak krótkim opracowaniu objąć analizą wszystkie dziedziny aktywności gospodarczej. Aby zachować przejrzystość wywodów, rozważania zostały skoncentrowane wokół prawnej regulacji jakości i bezpieczeństwa wyrobów, w ramach której zasadniczą rolę odgrywa system oceny zgodności wyrobów, który jest instytucją zawierającą zarówno regulacje o charakterze publicznoprawnym, jak i prywatnoprawnym.

4 M. Zdyb, Prawo publiczne gospodarcze, Kraków 1998, s. 25.

5 K. Strzyczkowski, Prawo publiczne gospodarcze, Warszawa 2009, s. 38, 43.

6 Zob. K. Kokocińska, Metoda regulacji stosunków prawnych w obszarze publicznego prawa gospodarczego (niejednorodność norm proceduralnych), [w:] Swoistość procedur publicznego prawa gospodarczego, red. B. Popowska, Poznań 2014, s. 79.

7 Zob. B. Liżewski, op. cit., s. 47. 
Celem niniejszego opracowania jest przedstawienie wpływu regulacji publicznoprawnych i prywatnoprawnych, tworzących system oceny zgodności wyrobów, na gospodarkę w sferze bezpieczeństwa produktów. Tezą artykułu jest twierdzenie, że przepisy prawa normujące system oceny zgodności wyrobów zawierają rozwiązania, w których istnieją współzależne konstrukcje prawne ze sfery prawa publicznego i prywatnego. Związek ten polega nie tylko na wzajemnym przenikaniu norm, lecz także na uzupełnianiu się złożonych konstrukcji prawnych i funkcjonowaniu norm heterogenicznych, co implikuje hybrydowy charakter systemu oceny zgodności.

\section{PRAWNA REGULACJA SYSTEMU OCENY ZGODNOŚCI WYROBÓW}

Analiza przepisów normujących system oceny zgodności wyrobów pod kątem wskazania stosunków prawnych o charakterze publicznoprawnym bądź prywatnoprawnym wymaga $\mathrm{w}$ pierwszej kolejności usystematyzowania regulacji prawnych kodyfikujących ową sferę stosunków gospodarczych. Nieodzowne jest przy tym zwrócenie uwagi na konotację tych aktów prawnych, wynikającą z silnych wpływów prawa europejskiego. Bezpieczeństwo produktów w warstwie normatywnej poddane zostało intensywnemu procesowi europeizacji. Sposób organizacji i działania systemu oceny zgodności wyrobów w Unii Europejskiej jest determinowany procesem integracji gospodarczej i politycznej państw członkowskich oraz utworzeniem Europejskiego Obszaru Gospodarczego zapewniającego swobodny przepływ kapitału, towarów, usług i ludzi (czyli realizacją koncepcji tzw. wspólnego rynku wewnętrznego) ${ }^{8}$. Jak zauważa J. Helios, Unia Europejska i globalna ekonomia wywierają wpływ na sposoby rozumienia i dystynkcje pomiędzy tym, co „publiczne”, a tym, co „prywatne”, przyjęte przez prawników wykształconych w kulturze i tradycji prawa stanowionego i common law. Ponadto rozwój europejskiego modelu socjalnego spowodował zatarcie prostej granicy między prawem publicznym a prawem prywatnym. Na progu nowej ery pojawiają się nowe koncepcje zarządzania, które nie mieszczą się ani w kategoriach prawa publicznego, ani prawa prywatnego ${ }^{9}$. Europejska dystynkcja systemu oceny zgodności wyrobów jest powodowana dążeniem prawodawcy unijnego do zapewnie-

8 Ogólne ramy prawne harmonizacji technicznej tworzą: decyzja Parlamentu Europejskiego i Rady nr 768/2008/WE z dnia 9 lipca 2008 r. w sprawie wspólnych ram dotyczących wprowadzania produktów do obrotu, uchylająca decyzję Rady 93/465/EWG (Dz.Urz. UE L 218/82, 13.08.2008), która ustanawia ogólne ramy o horyzontalnym charakterze dla prawodawstwa harmonizującego zasady wprowadzania do obrotu produktów, oraz rozporządzenie Parlamentu Europejskiego i Rady (WE) nr 765/2008 z dnia 9 lipca 2008 r. ustanawiające wymagania w zakresie akredytacji i nadzoru rynku odnoszące się do warunków wprowadzania produktów do obrotu i uchylające rozporządzenie (EWG) nr 339/93 (Dz.Urz. UE L 218, 13.08.2008).

9 J. Helios, op. cit., s. 12-13. 
nia wysokiego i jednolitego poziomu ochrony i bezpieczeństwa konsumentów w obrębie całej Unii Europejskiej. Ochrona praw konsumentów w kontekście gwarantowania dostępu do bezpiecznych wyrobów jest jedną z polityk realizowanych od wielu lat przez Unię Europejską ${ }^{10}$.

Normatywne podstawy systemu oceny zgodności (w tym status jednostek notyfikowanych, szczegółowe wymogi dla podmiotów gospodarczych, procedury weryfikacji spełniania przez produkt zasadniczych lub innych wymogów w polskim porządku prawnym) tworzą ustawa $z$ dnia 30 sierpnia 2002 r. o systemie oceny zgodności ${ }^{11}$ oraz ustawa z dnia 13 kwietnia 2016 r. o systemach oceny zgodności i nadzoru rynku ${ }^{12}$.

\section{KRYTERIA KWALIFIKACJI PRAWNEJ NORM REGULUJĄCYCH SYSTEM OCENY ZGODNOŚCI WYROBÓW}

Przyjmując stanowisko Z. Duniewskiej, że „sfera publiczna nie jest nigdy w pełni publiczna, tak jak sfera prywatna nie jest tylko w pełni prywatna" ${ }^{13}$, osiągnięcie założonego na wstępie celu wymaga przyjęcia optymalnego kryterium kwalifikacji, za pomocą którego można wskazać obiektywnie istniejące różnice między normami publicznoprawnymi i prywatnoprawnymi. W poszukiwaniach takiego środka, spośród kryteriów przedmiotowych, podmiotowych, zakresu kodyfikacji czy funkcji, najczęściej jako najbardziej precyzyjna i przydatna wskazywana jest metoda regulacji prawnej ${ }^{14}$. Metoda kształtowania sytuacji prawnej i stosunków prawnych uznawana jest $\mathrm{w}$ nauce prawa publicznego za kluczową $\mathrm{z}$ uwagi na niejednorodność norm prawnych mających zastosowanie w gospodarce, co stanowi konsekwencję poddania gospodarki różnym metodom regulacji prawnej ${ }^{15}$. Ciągłe poszerzanie publicznego prawa gospodarczego o nowe zagadnienia, które nie mają jednorodnego charakteru, wymaga subsydiarnego stosowania kryterium funkcjonalnego.

W niniejszych rozważaniach przyjęto metodę regulacji prawnej oraz kryterium o charakterze funkcjonalnym - rodzaj chronionego interesu. Do cech charakterystycznych publicznoprawnej metody regulacji zalicza się władztwo

10 Zob. A. Żywicka, M. Paździor, Ochrona praw konsumentów w dyrektywach harmonizacji technicznej - wybrane zagadnienia prawne, [w:] Powszechny i regionalne systemy ochrony praw człowieka. 70 lat po proklamowaniu Powszechnej Deklaracji Praw Człowieka. Osiagnięcia-bariery-nowe wyzwania i rozwiazania, red. J. Jaskiernia, K. Spryszak, Toruń 2019, s. 440-444.

11 T.j. Dz.U. 2019, poz. 155.

12 T.j. Dz.U. 2019, poz. 544.

13 Z. Duniewska, Prawo administracyjne - wprowadzenie. Prawo administracyjne $w$ systemie prawa, [w:] System Prawa Administracyjnego, t. 1: Instytucje prawa administracyjnego, red. R. Hauser, Z. Niewiadomski, A. Wróbel, Warszawa 2010, s. 159.

14 K. Kokocińska, op. cit., s. 82.

15 Zob. K. Strzyczkowski, op. cit., s. 38. 
O współzależnościach prawa publicznego i prywatnego w regulacjach gospodarczych... 153

administracyjne oraz brak równorzędności stron. Normy te określają warunki wykonywania władzy publicznej w gospodarce jako wynik ingerencji państwa w tej sferze. Prywatnoprawną metodę regulacji wyróżniają autonomia woli stron i szeroka swoboda w kształtowaniu treści wiążących je stosunków prawnych oraz równorzędność podmiotów. Przedmiotem regulacji prawnej są stosunki gospodarcze między podmiotami prawa.

System oceny zgodności wyrobów jest instytucją, w której napotykamy znaczne trudności w jednoznacznej kwalifikacji norm do sfery prawa publicznego lub do prawa prywatnego. Wybór publicznoprawnej lub prywatnoprawnej metody regulacji stosunków prawnych uzależniony jest także od założeń aksjologicznych, wartości i zasad systemu prawnego państwa ${ }^{16}$. Jak słusznie zauważa K. Kokocińska:

[...] w tej przestrzeni gospodarki, w której zasady swobody gospodarczej i wolności jednostki mają charakter nadrzędny, a możliwość szybkiego dostosowywania do zmieniających się warunków społeczno-gospodarczych (postulowana elastyczność działań) jest pożądana, powinna zostać zastosowana metoda regulacji prywatnoprawnej. Tam zaś, gdzie mamy do czynienia z potrzebą realizacji celów publicznych, które uzasadniają ingerencje państwa w gospodarkę ze względu na ochronę interesu publicznego (ogólnego) oraz ochronę praw innych uczestników obrotu, zastosowanie powinna znaleźć metoda publicznoprawna ${ }^{17}$.

Rozpatrując system oceny zgodności wyrobów w kontekście podstaw aksjologicznych, można uznać, że jego celem jest zapewnienie szeroko pojmowanego bezpieczeństwa wyrobów, co ma następnie zapewniać ochronę zdrowia i życia konsumentów oraz ochronę środowiska naturalnego. W tym zakresie regulacje prawne normujące system oceny zgodności chronią interes publiczny. Z drugiej strony idea wprowadzenia systemu oceny zgodności stanowi ukłon w stronę producentów i dystrybutorów wyrobów wprowadzanych do obrotu na rynek wewnętrzny. Jej celem jest gwarantowanie swobody przepływu towarów w ramach rynku wewnętrznego poprzez wprowadzenie jednolitych, mierzalnych kryteriów weryfikacji jakości i bezpieczeństwa produktów. Ma to obniżać koszty produkcji i ułatwiać przepływ towarów na rynku wewnętrznym, a tym samym kształtować swobodę przedsiębiorczości. System oceny zgodności wyrobów chroni wobec tego również interesy jednostkowe przedsiębiorców. Wyważenie tych przeciwstawnych z racji swej natury interesów - publicznego i prywatnego - w instytucjach prawnych jest trudne, aczkolwiek możliwe, czego dowodem jest konstrukcja systemu oceny zgodności.

16 Zob. M. Safjan, Pojęcie i systematyka prawa prywatnego, [w;] System Prawa Prywatnego, t. 1: Prawo cywilne-czéść ogólna, red. M. Safjan, Warszawa 2007, s. 42.

17 Por. K. Kokocińska, op. cit., s. 83; K. Strzyczkowski, op. cit., s. 38; L. Kieres, [w:] Administracyjne prawo gospodarcze, red. A. Borkowski, A. Chełmoński, M. Guziński, K. Kiczka, L. Kieres, T. Kocowski, M. Szydło, Wrocław 2009, s. 29. 


\section{SYSTEM OCENY ZGODNOŚCI WYROBÓW - W KIERUNKU PRYWATYZACJI PRAWA PUBLICZNEGO CZY PUBLICYZACJI PRAWA PRYWATNEGO?}

Zdania doktryny na temat pozytywnych i negatywnych przejawów procesu publicyzacji prawa prywatnego i prywatyzacji prawa publicznego są podzielo$\mathrm{n}^{18}$. W wyniku obu tych zjawisk dochodzi do stosowania przez podmioty administrujące (administrację publiczną) form działania właściwych prawu prywatnemu (głównie umów). W niektórych przypadkach trudno jednoznacznie przesądzić o charakterze prawnym działań oraz ustalić kierunek zapożyczenia - z prawa publicznego do prawa prywatnego czy odwrotnie. W moim przekonaniu można mówić o tworzeniu tzw. hybrydowych konstrukcji prawnych łączących elementy publiczno- i prywatnoprawne o równorzędnym, sprzężonym oddziaływaniu. Można zatem sformułować tezę o kształtowaniu się zjawiska współzależności norm publicznoprawnych i prywatnoprawnych w heterogenicznych instytucjach prawnych, których zasadniczym celem jest godzenie interesu publicznego i interesów jednostkowych. Ten trend wywołują nowe potrzeby, zmieniające się realia społeczne i gospodarcze (m.in. rozwój cywilizacyjny czy postęp techniczny) tudzież procesy globalizacyjne. Do takich sytuacji dochodzi wówczas, gdy dotychczasowe standardowe formy działania nie są w stanie sprostać nowym potrzebom społecznym i gospodarczym, konieczne jest więc poszukiwanie nowych rozwiązań prawnych, dostosowanych do bieżących wymogów ${ }^{19}$.

System oceny zgodności z racji swej natury i zastosowania w weryfikacji różnorodnych parametrów stricte technicznych i jakościowych wyrobów najczęściej jest analizowany w wymiarze technicznym, tzn. norm technicznych stosowanych w poszczególnych procedurach weryfikacji określonego rodzaju wyrobów (tzw. modułach oceny). Rzadko oceniany jest charakter norm prawnych, tworzących jego podwaliny konstrukcyjne. W rozumieniu jurydycznym „ocena zgodności” stanowi przede wszystkim kategorię prawa materialnego. Przedstawienie systemu w sposób instytucjonalny zarówno w aspekcie warunków techniczno-prawnych oceny zgodności, jak i (dalej) mechanizmów nadzoru rynku pozwala jednak

18 Por. np. J. Starościak, Prawne formy i metody działania administracji, [w:] System Prawa Administracyjnego, red. T. Rabska, J. Łętowski, t. 3, Wrocław 1978, s. 44-46; A. Żurawik, Problem publicyzacji prawa prywatnego w kontekście ustrojowym, „Państwo i Prawo” 2010, z. 5, s. 39; P. Bieś-Srokosz, Tendencje zmian prawnych form realizacji zadań publicznych, [w:] Prawo administracyjne dziś i jutro, red. J. Jagielski, M. Wierzbowski, Warszawa 2018, s. 191; B. Dolnicki, R. Cybulska, Nowe dwustronne formy działania administracji publicznej - zagadnienia wybrane, [w:] Koncepcja systemu prawa administracyjnego, red. J. Zimmermann, Warszawa 2007, s. 471-473.

19 A. Żywicka, Instrumenty administracyjnoprawne w systemie zapewniania bezpieczeństwa wyrobów - kierunki rozwoju systemu oceny zgodności, [w:] Prawo administracyjne dziś..., s. 286. 
O współzależnościach prawa publicznego i prywatnego w regulacjach gospodarczych... 155

dostrzec $\mathrm{w}$ nim również normy proceduralne ${ }^{20} \mathrm{o}$ zdecydowanie niejednorodnym charakterze prawnym.

Instytucję systemu oceny zgodności wyrobów tworzą dwa obszary. Pierwszy z nich obejmuje certyfikację jednostek notyfikowanych i nadzór nad tymi jednostkami, normowany regulacją administracyjnoprawną. Drugi zaś obejmuje kontrolę spełniania przez wyroby zasadniczych i innych wymagań i jest normowany regulacją cywilnoprawną ${ }^{21}$. Ujmując instytucję w szerszym znaczeniu, regulacja administracyjnoprawna obejmuje, co oczywiste, nadzór rynku nad wyrobami wprowadzonymi do obrotu.

Działalność jednostek notyfikowanych w zakresie procedur oceny zgodności stanowi działalność gospodarczą w rozumieniu art. 4 ustawy z dnia 6 marca 2018 r. - Prawo przedsiębiorców ${ }^{22}$, dlatego te podmioty podlegają wszystkim obowiązkom publicznoprawnym związanym z legalizacją i prowadzeniem działalności gospodarczej wynikającym z przepisów prawa. Szczególne obowiązki w tym zakresie przewiduje ustawa o systemach oceny zgodności i nadzoru rynku. Regulacja administracyjnoprawna determinuje tryb nadawania uprawnień jednostkom przeprowadzającym ocenę zgodności wyrobów (tzw. jednostkom notyfikowanym).

Proces nadawania uprawnień do świadczenia usług z zakresu oceny zgodności stanowi swoistą, złożoną konstrukcję trybu udzielenia zezwolenia na prowadzenie działalności gospodarczej. Jednostki notyfikowane po uzyskaniu zezwolenia są bowiem uprawnione do świadczenia usług w obrębie Unii Europejskiej. Z tego względu akredytacja (czyli weryfikacja podmiotu ubiegającego się o uzyskanie statusu jednostki notyfikowanej) odbywa się najpierw na poziomie krajowym, a następnie wymaga akceptacji Komisji Europejskiej. Usługi z zakresu oceny zgodności są realizowane głównie przez podmioty niepubliczne, dlatego dążeniem prawodawcy unijnego jest zapewnienie wiarygodnego poświadczenia kompetencji podmiotu do wykonywania działalności z zakresu oceny zgodności. Zadania w systemie oceny zgodności z zakresu weryfikacji kompetencji podmiotów ubiegających się o uzyskanie notyfikacji są realizowane przez organy administrujące: Polskie Centrum Akredytacji, ministra właściwego ds. gospodarki oraz innych ministrów właściwych ds. obszaru udzielanej autoryzacji w trybie administracyjnym.

${ }^{20}$ Zob. L. Kieres, A. Borkowski, K. Kiczka, T. Kocowski, M. Guziński, M. Szydło, Instrumenty administracyjnoprawne w systemie oceny zgodności, [w:] Instrumenty i formy prawne działania administracji gospodarczej, red. B. Popowska, K. Kokocińska, Poznań 2009, s. 230; A. Żywicka, op. cit., s. 283-291.

${ }^{21}$ Zob. K. Kiczka, O obszarach europeizacji publicznego prawa gospodarczego, [w:] Europeizacja publicznego prawa gospodarczego, red. H. Gronkiewicz-Waltz, K. Jaroszyński, Warszawa 2011, s. 276.

22 T.j. Dz.U. 2019, poz. 1292. 
Procedura nadawania uprawnień podmiotom ubiegającym się o status jednostki notyfikowanej została unormowana trzyetapowo, w drodze trzech aktów uprawniających: akredytacji, autoryzacji i notyfikacji. Dwa pierwsze odbywają się na poziomie krajowym, ostatni zaś na poziomie unijnym. Przyjmując podział dokonany przez K. Kiczkę, w systemie nadawania uprawnień podmiotom ubiegającym się o status jednostki notyfikowanej można wyróżnić: administracyjne akty kwalifikujące ,uprawniające” (kreujące główne uprawnienia - publiczne prawa podmiotowe - podmiotów) oraz administracyjne akty kwalifikujące „,zobowiązujące" (kształtujące głównie powinności prawne) ${ }^{23}$. Pozostaje jeszcze do doprecyzowania forma ograniczania działalności gospodarczej przyjęta na gruncie ustawy o systemach oceny zgodności i nadzoru rynku.

W świetle art. 22 ustawy o systemach oceny zgodności i nadzoru rynku uzyskanie akredytacji jest pierwszym etapem potwierdzenia kompetencji jednostki w zakresie prawidłowej realizacji uprawnień, której udziela Polskie Centrum Akredytacji - agencja rządowa powołana do realizacji zadań publicznych z zakresu akredytacji w ramach systemu oceny zgodności. Zważywszy na status Polskiego Centrum Akredytacji, będzie to administracyjny akt kwalifikujący. Jego natura prawna jest jednak bardziej złożona. Trudno go jednoznacznie przyporządkować do jednej kategorii, ponieważ certyfikat akredytacji wykazuje zarówno cechy administracyjnego aktu kwalifikującego o charakterze uprawniającym, jak $i$ aktu zobowiązującego ${ }^{24}$. Drugim etapem włączania jednostek do oceny zgodności jest decyzja autoryzacyjna, która wymaga szerszej analizy. Autoryzacji udziela w drodze kwalifikowanej decyzji administracyjnej minister lub kierownik urzędu centralnego właściwy ze względu na przedmiot oceny zgodności - najczęściej jest to minister właściwy ds. gospodarki lub infrastruktury. Autoryzacja oznacza zakwalifikowanie jednostki do procesu notyfikacji, jest to akt kwalifikujący. Co istotne, trudno w sposób oczywisty zakwalifikować ten akt administracyjny jako klasyczne zezwolenie, mimo że warunki i tryb wydawania zezwoleń nie są jednolite dla wszystkich rodzajów działalności gospodarczej objętych tą formą reglamentacji. Tryb udzielenia autoryzacji i skutki prawne pozwalają go sklasyfikować jako swoisty akt reglamentacji działalności gospodarczej - zezwolenie warunkowe. W nauce publicznego prawa gospodarczego przyjmuje się, że zezwoleniem jest akt zgody uprawnionego organu administracji publicznej, udzielo-

${ }^{23}$ Zob. K. Kiczka, Administracyjne akty kwalifikujace w działalności gospodarczej, Wrocław 2006, s. 240-241.

24 Por. ibidem, s. 260; R. Hauser J. Drachal, E. Mzyk, Dwuinstancyjne sadownictwo administracyjne. Omówienie podstawowych zasad i instytucji procesowych. Teksty aktów prawnych, Warszawa 2003, s. 11; B. Adamiak, Wtaściwość instancyjna w postepowaniu podatkowym, [w:] Ius et lex. Księga jubileuszowa Profesora Andrzeja Kabata, red. S. Pikulski, Olsztyn 2004, s. 24; M. Wierzbowski, Jakość wyrobów. Zagadnienia administracyjnoprawne, Wrocław-WarszawaKraków-Lódź 1984, s. 138. 
ny przedsiębiorcy zainteresowanemu podjęciem i wykonywaniem, na warunkach określonych przepisami prawa, określonego rodzaju działalności gospodarczej ${ }^{25}$. Zezwolenie może być traktowane jako warunek podejmowania w sposób legalny określonej działalności gospodarczej bądź jako uchylenie ogólnego zakazu wynikającego z norm zezwalających. Zezwolenie można też ujmować jako zespół obowiązków wynikających $\mathrm{z}$ ustaw, nałożonych na przedsiębiorcę zamierzającego podjąć i prowadzić działalność gospodarczą w danej dziedzinie. Powyższe obowiązki sprowadzają się do spełnienia szczególnych warunków określonych prawem, równolegle z obowiązkami o charakterze ogólnym dotyczącymi wszystkich przedsiębiorców. Zezwolenie przybiera formę decyzji administracyjnej, która stwierdza, że przedsiębiorca spełnia powyższe warunki oraz że nie zachodzą przeszkody w podejmowaniu i prowadzeniu danego rodzaju działalności gospodarczej $^{26}$. Decyzja autoryzacyjna zawiera uprawnienie warunkowe do podjęcia działalności gospodarczej; prawo to powstaje dopiero po dokonaniu zgłoszenia - notyfikacji do Komisji Europejskiej. Jednak już w przypadku decyzji odmownej wnioskodawcy przysługują administracyjne środki ochrony prawnej: odwołanie i skarga do sądu administracyjnego. Trzecim etapem kwalifikacji jednostki do procesu oceny zgodności jest notyfikacja, dokonywana w formie zgłoszenia Komisji Europejskiej i państwom członkowskim Unii Europejskiej autoryzowanej jednostki do wykonywania czynności określonych w ramach oceny zgodności. Organem właściwym w sprawie wykonania notyfikacji w Komisji Europejskiej jest właściwy minister. Zadania organu notyfikującego zostały przyznane ministrowi właściwemu ds. gospodarki z uwagi na jego wiodącą rolę w systemie autoryzacji. Dopiero w wyniku notyfikacji jednostka nabywa uprawnienie do przeprowadzania oceny zgodności według procedur oceny zgodności określonych w bezpośrednio stosowanym unijnym prawodawstwie harmonizacyjnym lub w przepisach wdrażających te regulacje. Następstwem złożonego trybu nadawania uprawnień jest nadzór nad prawidłowym świadczeniem usług przez jednostki notyfikowane sprawowany przez właściwego ministra, przy czym uprawnienia do kontroli działalności tych podmiotów zostały przyznane Polskiemu Centrum Akredytacji.

Regulacja prywatnoprawna determinuje sferę działalności podmiotów świadczących usługi z zakresu oceny zgodności. Sfera świadczenia tych usług została poddana prywatyzacji zupełnej. Na gruncie systemu oceny zgodności wszystkie usługi są realizowane w oparciu o klasyczne instrumenty prawa cywilnego (głównie umowę zlecenia), ze szczególnym zastosowaniem art. 750 ustawy z dnia

${ }_{25}$ Zob. W. Kubala, Zezwolenie na wykonywanie działalności gospodarczej, „Monitor Prawniczy" 2000, nr 7, s. 417.

26 Zob. M.A. Waligórski, Koncesje, zezwolenia i licencje w polskim administracyjnym prawie gospodarczym, Poznań 2012, s. 749. 
23 kwietnia 1964 r. - Kodeks cywilny²7, w myśl którego: „Do umów o świadczenie usług, które nie są uregulowane innymi przepisami, stosuje się odpowiednio przepisy o zleceniu". Są to usługi, które polegają na świadczeniu w interesie innej osoby oznaczonych czynności faktycznych oraz zespołu czynności prawnych i faktycznych odpłatnie lub nieodpłatnie ${ }^{28}$. Przedmiot umowy zlecenia w ramach oceny zgodności stanowi odpłatne sprawdzenie przez jednostkę notyfikowaną (zleceniobiorcę) konkretnych parametrów technicznych wyrobu zgodnie z obowiązującym modułem oceny oraz sporządzenie certyfikatu jakości tego wyrobu na rzecz producenta lub dystrybutora (zleceniodawcy). Zlecenie może przewidywać dokonywanie wielu czynności, także o nieustalonej z góry liczbie, w sposób stały $^{29}$ (może np. dotyczyć wielu wyrobów). W opisanej sytuacji mamy do czynienia ze zleceniem stałym. Jest ono w judykaturze definiowane jako zobowiązanie ugruntowane, $\mathrm{z}$ reguły trwa dłuższy czas i wiąże strony ściśle, a nie okazjonalnie. Umowy zlecenia, których przedmiotem jest świadczenie usług z zakresu oceny zgodności, zawierane są z reguły na czas określony, lecz wykazują one cechy stałości stosunku zlecenia, gdyż są zaprojektowane na przyszłość i posiadają cechy ciągłości ${ }^{30}$. Umowy zawierane są w trybie cywilnoprawnym, zazwyczaj w drodze oferty lub przetargu. To przedsiębiorca wybiera najkorzystniejszą dla siebie ofertę według reguł wolnego rynku i konkurencji. Konsekwencją regulacji cywilnoprawnej jest ponoszenie przez jednostkę notyfikowaną odpowiedzialności kontraktowej z tytułu niewykonania lub nienależytego wykonania umowy wobec zleceniodawcy - przedsiębiorcy. W razie sporu postępowanie w kwestii dochodzenia roszczenia (odszkodowania z tytułu niewykonania lub nienależytego wykonania umowy) odbywa się przed sądem powszechnym. Jednostka notyfikowana ponosi odpowiedzialność na zasadzie art. 471 k.c., jest obowiązana do naprawienia szkody wynikłej z tytułu niewykonania lub nienależytego wykonania zobowiązania, chyba że niewykonanie lub nienależyte wykonanie zobowiązania jest następstwem okoliczności, za które jednostka nie ponosi odpowiedzialności.

27 T.j. Dz.U. 2019, poz. 1145. W myśl art. 734 § 1 k.c. przez umowę zlecenia przyjmujący zlecenie zobowiązuje się do dokonania określonej czynności prawnej dla dającego zlecenie.

28 Zob. m.in. L. Ogiegło, [w:] System Prawa Prywatnego, t. 7: Prawo zobowiazań - część szczegółowa, red. J. Rajski, Warszawa 2011, s. 574; W. Czachórski, A. Brzozowski, M. Safjan, E. Skowrońska-Bocian, Zobowiązania. Zarys wykładu, Warszawa 2009, s. 480; Z. Radwański, J. Panowicz- Lipska, Zobowiazania. Część szczegółowa, Warszawa 2012, s. 180; wyrok SN z dnia 5 grudnia 2013 r., V CSK 30/13, LEX nr 1422123.

29 Zob. wyrok SA w Łodzi z dnia 18 sierpnia 2015 r., III AUa 1482/14, LEX nr 1916665.

30 Zob. P. Zakrzewski, Komentarz do art. 750 Kodeksu cywilnego, [w:] Kodeks cywilny. Komentarz, t. 4: Zobowiąania. Część szczególna, red. M. Fras, M. Habdas, LEX/el. 2018; postanowienie SN z dnia 15 maja 2007 r., V CZ 32/07, LEX nr 485996. 


\section{PODSUMOWANIE}

Złożoność publicznoprawnych stosunków gospodarczych wymaga ciągłej adaptacji do zmieniających się uwarunkowań gospodarczo-społecznych, co rodzi potrzebę tworzenia nowych konstrukcji prawnych, często określanych w nauce publicznego prawa gospodarczego jako szczególne, nietypowe bądź hybrydowe, powstałych jako efekt przenikania norm prawa prywatnego do prawa publicznego ${ }^{31}$. Przykładem tego zjawiska jest zaprezentowana wyżej instytucja systemu oceny zgodności wyrobów. $Z$ uwagi na zwięzłą formułę opracowania $\mathrm{w}$ artykule zostały zaprezentowane tylko wybrane wątki stanowiące niejako sztandarowe wzorce przenikania i współzależności norm publicznoprawnych i prywatnoprawnych $\mathrm{w}$ instytucjach prawnych w systemie oceny zgodności wyrobów. Normatywna regulacja bezpieczeństwa i jakości wyrobów jest bowiem obszarem, w którym opisane zjawiska zachodzą ze szczególną intensywnością. Jednakże przeprowadzone powyżej rozważania pozwalają skonstatować, że trudno jest jednoznacznie przyporządkować instytucję systemu oceny zgodności w dychotomicznym ujęciu tylko do prawa publicznego lub wyłącznie do prawa prywatnego. Można tutaj zaobserwować współzależność regulacji publicznoprawnych i prywatnoprawnych, co potwierdza postawioną na wstępie tezę o wzajemnym przenikaniu i uzupełnianiu się złożonych konstrukcji prawnych i funkcjonowaniu norm heterogenicznych w systemie oceny zgodności. Instytucjonalnie system oceny zgodności wyrobów jest złożoną konstrukcją prawną, w którym współistnieją normy publicznoprawne i prywatnoprawne, których celem jest pogodzenie interesu publicznego i prywatnego.

\section{BIBLIOGRAFIA}

\section{Literatura}

Adamiak B., Właściwość instancyjna w postępowaniu podatkowym, [w:] Ius et lex. Księga jubileuszowa Profesora Andrzeja Kabata, red. S. Pikulski, Olsztyn 2004.

Bieś-Srokosz P., Tendencje zmian prawnych form realizacji zadań publicznych, [w:] Prawo administracyjne dziś i jutro, red. J. Jagielski, M. Wierzbowski, Warszawa 2018.

Czachórski W., Brzozowski A., Safjan M., Skowrońska-Bocian E., Zobowiąania. Zarys wykładu, Warszawa 2009.

Dolnicki B., Cybulska R., Nowe dwustronne formy działania administracji publicznej-zagadnienia wybrane, [w:] Koncepcja systemu prawa administracyjnego, red. J. Zimmermann, Warszawa 2007.

Duniewska Z., Prawo administracyjne - wprowadzenie. Prawo administracyjne $w$ systemie prawa, [w:] System Prawa Administracyjnego, t. 1: Instytucje prawa administracyjnego, red. R. Hauser, Z. Niewiadomski, A. Wróbel, Warszawa 2010.

Hauser R., Drachal J., Mzyk E., Dwuinstancyjne sądownictwo administracyjne. Omówienie podstawowych zasad i instytucji procesowych. Teksty aktów prawnych, Warszawa 2003.

31 Por. L. Kieres, Publiczne prawo gospodarcze - nowe kierunki-nowe instytucje, [w:] Nowe problemy badawcze w teorii prawa administracyjnego, red. J. Boć, A. Chajbowicz, Wrocław 2009, s. 279-280; K. Kokocińska, op. cit., s. 780. 
Helios J., Publicyzacja prawa prywatnego - prywatyzacja prawa publicznego w kontekście rozważań nad prawem europejskim, „Przegląd Prawa i Administracji” 2013, nr 92.

Kiczka K., Administracyjne akty kwalifikujące w działalności gospodarczej, Wrocław 2006.

Kiczka K., O obszarach europeizacji publicznego prawa gospodarczego, [w:] Europeizacja publicznego prawa gospodarczego, red. H. Gronkiewicz-Waltz, K. Jaroszyński, Warszawa 2011.

Kieres L., [w:] Administracyjne prawo gospodarcze, red. A. Borkowski, A. Chełmoński, M. Guziński, K. Kiczka, L. Kieres, T. Kocowski, M. Szydło, Wrocław 2009.

Kieres L., Publiczne prawo gospodarcze - nowe kierunki - nowe instytucje, [w:] Nowe problemy badawcze w teorii prawa administracyjnego, red. J. Boć, A. Chajbowicz, Wrocław 2009.

Kieres L., Borkowski A., Kiczka K., Kocowski T., Guziński M., Szydło M., Instrumenty administracyjnoprawne $w$ systemie oceny zgodności, [w:] Instrumenty i formy prawne działania administracji gospodarczej, red. B. Popowska, K. Kokocińska, Poznań 2009.

Kokocińska K., Metoda regulacji stosunków prawnych w obszarze publicznego prawa gospodarczego (niejednorodność norm proceduralnych), [w:] Swoistość procedur publicznego prawa gospodarczego, red. B. Popowska, Poznań 2014.

Kubala W., Zezwolenie na wykonywanie działalności gospodarczej, „Monitor Prawniczy” 2000, nr 7.

Liżewski B., Prawo publiczne a prawo prywatne - wybrane uwagi teoretyczne na temat hybrydyzacji instytucji prawnych, „Zeszyty Naukowe KUL”2018, nr 4.

Ogiegło L., [w:] System Prawa Prywatnego, t. 7: Prawo zobowiąań - część szczegółowa, red. J. Rajski, Warszawa 2011.

Radwański Z., Panowicz-Lipska J., Zobowiązania. Część szczegółowa, Warszawa 2012.

Rodziewicz P., Prawo prywatne oraz prawo publiczne z perspektywy prawa międzynarodowego, „Studia Prawa Prywatnego” 2017, nr 3-4.

Safjan M., Pojęcie i systematyka prawa prywatnego, [w;] System Prawa Prywatnego, t. 1: Prawo cywilne - część ogólna, red. M. Safjan, Warszawa 2007.

Starościak J., Prawne formy i metody działania administracji, [w:] System Prawa Administracyjnego, red. T. Rabska, J. Łętowski, t. 3, Wrocław 1978.

Strzyczkowski K., Prawo publiczne gospodarcze, Warszawa 2009.

Waligórski M.A., Koncesje, zezwolenia i licencje $w$ polskim administracyjnym prawie gospodarczym, Poznań 2012.

Wierzbowski M., Jakość wyrobów. Zagadnienia administracyjnoprawne, Wrocław-WarszawaKraków-Lódź 1984.

Zakrzewski P., Komentarz do art. 750 Kodeksu cywilnego, [w:] Kodeks cywilny. Komentarz, t. 4: Zobowiązania. Część szczególna, red. M. Fras, M. Habdas, LEX/el. 2018.

Zdyb M., Prawo publiczne gospodarcze, Kraków 1998.

Żurawik A., Problem publicyzacji prawa prywatnego w kontekście ustrojowym, „Państwo i Prawo” 2010, z. 5.

Żywicka A., Instrumenty administracyjnoprawne w systemie zapewniania bezpieczeństwa wyrobów - kierunki rozwoju systemu oceny zgodności, [w:] Prawo administracyjne dziś i jutro, red. J. Jagielski, M. Wierzbowski, Warszawa 2018.

Żywicka A., Paździor M., Ochrona praw konsumentów w dyrektywach harmonizacji technicznejwybrane zagadnienia prawne, [w:] Powszechny i regionalne systemy ochrony praw człowieka. 70 lat po proklamowaniu Powszechnej Deklaracji Praw Człowieka. Osiagnięcia - bariery nowe wyzwania i rozwiązania, red. J. Jaskiernia, K. Spryszak, Toruń 2019.

\section{AKTY PRAWNe}

Decyzja Parlamentu Europejskiego i Rady nr 768/2008/WE z dnia 9 lipca 2008 r. w sprawie wspólnych ram dotyczących wprowadzania produktów do obrotu, uchylająca decyzję Rady 93/465/ EWG (Dz.Urz. UE L 218/82, 13.08.2008). 
O współzależnościach prawa publicznego i prywatnego w regulacjach gospodarczych... 161

Rozporządzenie Parlamentu Europejskiego i Rady (WE) nr 765/2008 z dnia 9 lipca 2008 r. ustanawiające wymagania w zakresie akredytacji i nadzoru rynku odnoszące się do warunków wprowadzania produktów do obrotu i uchylające rozporządzenie (EWG) nr 339/93 (Dz.Urz. UE L 218, 13.08.2008).

Ustawa z dnia 23 kwietnia 1964 r. - Kodeks cywilny (t.j. Dz.U. 2019, poz. 1145).

Ustawa z dnia 30 sierpnia 2002 r. o systemie oceny zgodności (t.j. Dz.U. 2019, poz. 155).

Ustawa z dnia 13 kwietnia 2016 r. o systemach oceny zgodności i nadzoru rynku (t.j. Dz.U. 2019, poz. 544).

Ustawa z dnia 6 marca 2018 r. - Prawo przedsiębiorców (t.j. Dz.U. 2019, poz. 1292).

\section{ORZECZNICTWO}

Postanowienie SN z dnia 15 maja 2007 r., V CZ 32/07, LEX nr 485996.

Wyrok SA w Łodzi z dnia 18 sierpnia 2015 r., III AUa 1482/14, LEX nr 1916665.

Wyrok SN z dnia 5 grudnia 2013 r., V CSK 30/13, LEX nr 1422123.

\section{SUMMARY}

The article presents the institution of the conformity assessment system regarding the requirements as an example of a hybrid legal institution which is based on the standards of the public law and private law. The author analyzed the interdependence of the regulations in the public law and private law in the solutions introduced in the Act of 13 April 2016 on Conformity Assessment Systems and Market Supervision.

Keywords: product conformity assessment; privatization of public law; publicization of private law

\section{STRESZCZENIE}

W artykule zaprezentowana została instytucja systemu oceny zgodności z wymaganiami jako przykład hybrydowej instytucji prawnej, której konstrukcja opiera się na normach publicznoprawnych i prywatnoprawnych. Autorka zanalizowała współzależność regulacji publicznoprawnych i prywatnoprawnych w rozwiązaniach zawartych w ustawie z dnia 13 kwietnia 2016 r. o systemach oceny zgodności i nadzoru rynku.

Słowa kluczowe: ocena zgodności wyrobów; prywatyzacja prawa publicznego; publicyzacja prawa prywatnego 